\title{
Fiscal Policy Shocks and the Dynamics of Asset Prices in Turkey
}

\author{
Prof. Dr. Mehmet Balc1lar (Eastern Mediterranean University, Cyprus) \\ Ph. D. Candidate Evrim Tören (Eastern Mediterranean University, Cyprus)
}

\begin{abstract}
Asset markets and the asset prices affect financial institutions, consumers, producers and policy makers while they are making decisions. There is an important relationship not only between the financial market and banking system but also between the housing market and the credit market. Therefore, the study analyzes the impact of fiscal policy on asset prices by using beyasian vector autoregressive models. The sample data has been gathered from the Central Bank of the Republic of Turkey. The aim is to demonstrate the effects of fiscal policy shocks on stock prices and housing prices. The data covers the period between 1988:Q1 and 2014:Q2. Overall, the results confirm that the spending shocks coming from fiscal policy have a greater influence on the stock prices. In addition, the government revenue shocks are more influential on the house prices compared to the stock prices in Turkey.
\end{abstract}

\section{Introduction}

There are two different cycles in asset prices. These cycles are called the boom cycle and the bust cycle, respectively. They influence the macroeconomic stability in many countries. The boom cycle is defined as a period of great prosperity or rapid economic growth. It favorably affects output and price stability in the economy. In contrast, the bust cycle is a depression, which dramatically influences output and price stability. Due to the existence of the boom and bust cycles, the global financial crisis has existed recently. Hence, this event makes the macroeconomists aware of the business cycle because there is a decline in the economic, business and financial markets.

Although the signals from the stock market are sometimes interpreted falsely; the housing sector and stock market affect the business cycle movements. For example, the higher interest rates have resulted in in a temporary problem for the housing sector and stock markets in World War II period (Stock and Watson 2003). Thus, the researchers analyze the reasons for continuous loss of economic activity.

The studies based on the relationship between economic policy and asset markets generally examine the monetary policy because this policy is represented as an important factor influencing the business cycle in the economy (Bjornlord and Leitama 2009; Sousa 2010, 2012). However, fiscal policy is also influential when the zero interest rate lower bound is experienced. Schuknecht von Hagen and Wolswijk (2009) contend that the persistent incentives belonging to fiscal policy cause unsustainable conditions for government bond markets. Therefore, the researchers have started to carry out the connection between monetary policy and fiscal stability by ecamining business cycle fluctuations. Their aim is to identify the reasons for the resent financial crisis (Sousa 2010; Castro 2011).

Since producers, consumers, financial experts and government officials take into consideration the properties of asset markets and their prices, the nexus between the financial market and the banking system should be analyzed comprehensively. According to Afonso and Sousa (2011), this linkage creates strong influences in the state of financial disturbance and uncertainty. In addition, the relationship between the credit market and the housing sector also presents important effects, too. Therefore, there are crucial studies, which focus on the connection between the variables that belong to macroeconomics, wealth and asset returns in the literature (Sousa 2010; Afonso and Sousa 2011).

Aye, Balcilar, et al. (2013) state that there are limited studies, which show the process of transmitting innovations of fiscal policy to asset markets. The studies generally focus on the European and the U.S. markets (Afonso and Sousa 2011, 2012; Agnello and Sousa 2011).

For Afonso and Sousa (2011, 2012), the distinct channels coming from fiscal policy have an impact on the stock markets and housing sector. Hence, it is obvious that fiscal policy influences risk spreads in the stock markets. According to the researches on the effect of fiscal policy on the housing sector, the researchers claim that there are direct and indirect impacts of fiscal policy on the housing markets. The direct influences exist through taxes and subsidies on homeowners whereas the indirect effect of fiscal policy replaces through changes in macroeconomic variables. In this respect, the researchers should take into account the importance of fiscal policy properly, if they aim to reveal relevant facts about the development of housing sector and the changes in the stock market.

As stated above, the studies mostly examine the macroeconomic influences of fiscal policy and the effects of stock markets on the business cycle in the developed countries. In other words, the studies don't analyze the relationship between the actions of fiscal policy and improvements in asset prices for small-open economies in the literature. 
For Mountford and Uhlig (2009), the deficit financed tax cuts lead to beneficial consequences to improve gross domestic product (GDP) for the U.S. economy when they have worked on the effects of fiscal policy by using vector autoregressions for the quarterly data from 1955 to 2000. In addition, Afonso and Sousa (2011, 2012) notice that there is a small effect of government spending shocks on GDP but a varied impact on housing prices and a fall in stock prices. Afonso and Sousa (2012) also notice that there is a mixed influence of government revenue shocks on housing prices and a positive and small influence on stock prices. When the quarterly data from 1966:Q1 to 2011:Q2 in South Africa is analyzed, the results confirm that fiscal spending shocks have a greater effect on stock prices than the house prices. By contrast, the revenue shocks are more influential than the spending shocks in case of the house prices in South Africa (Aye, Balcilar, et al. 2013).

In this study, Turkish economy is examined because Turkey has experienced an extraordinary period of economic growth since 2003. For Coskun (2011), Turkey has this economic growth for several reasons such as the full membership candidacy for European Union (EU), the developments in political and economic stability and the increase in liquidity coming from direct and portfolio investments. Where Turkey is concerned, there are limited studies, which examine the effects of fiscal policy shocks specified in the vector autogressive models (VAR). There are some researches which address the effects of fiscal policy and macroeconomic alternatives on wealth, stock and housing returns in Turkey (Caporole and Sousa 2015; Yeldan 1997; Voyvoda and Erinc 2005; Berument and Tasci 2004; Ertugrul and Selcuk 2001; and Anand and van Wijnbergen 1989). The results of these studies generally conclude that fiscal and monetary policies have a positive influence on stock and house prices when they are adapted in a truthful way for the Turkish economy.

However, in the literature, there have been studies examining a disturbance that leads to instability in an economy. For the researches, the disturbance generally replaces because of the drawbacks in monetary policy, fiscal policy and business cycle. Sims $(1972,1980)$ indicates the usefulness of VAR method while analyzing the influences of monetary policy and fiscal policy. Many researchers use this method to show the dynamics of monetary policy shock. In their models VAR models, the monetary aggregate and interest rate are included for research findings.

After the identification of the VAR models by Sims (1972, 1980), Uhlig (2005) proposes a monetary policy shock. In Uhlig's (2005) model, sign restrictions are specified on impulse responses of determined variables for particular periods after the shock. Then, Mountford and Uhlig (2009) use Uhlig (2005) and determine fiscal policy shocks in their models. These shocks are specified as revenue or spending shocks by the government. In Mountford and Uhlig (2009), the sign restrictions are specified while determining the behavior of fiscal policy shocks. In this respect, this study includes the method of Mountford and Uhlig (2009) to analyze the influence of fiscal policy shocks on the stock prices and house prices for Turkey including the period between 1988:Q1 and 2014:Q4.

The variables in the VAR method are converted into real values. The variables in the model are stock prices, house prices, consumption, nonresidential investment, GDP, government expenditure, government revenue, interest rate and consumer price index (CPI) for the analyses. While defining the shocks of fiscal policy, this study also focuses on Afonso and Sousa (2011), Agnello, Castro and Sousa (2012) and Agnello and Sousa (2013). Through the use of sign restrictions proposed by Mountford and Uhlig (2009), this study provides the understanding of fiscal policy scenarios for Turkey.

The study covers a wider emphasis on fiscal policy shocks in Turkey. Throughout the study, the aim is to demonstrate the influences of these shocks concurrently on the stock prices, house prices and macroeconomic variables. The study consists of five sections. Section 2 introduces the particular econometric procedure identified by Mountford and Uhlig (2009). Section 3 reveals the properties of the data used. Section 4 provides the research findings based on the reactions of impulse responses of the series to the government spending and government revenue shocks. Finally, section 5 presents a brief conclusion of the important concerns in the study.

\section{Methodology}

The methodology of the study is based on the analyses of fiscal policy shocks because this issue is very important in the economic literature. When the researchers use Mountford and Uhlig (2009) in their studies, they can easily analyze the influences of fiscal policy on the stock prices and housing prices at the same time. Through the use of Mountford and Uhlig (2009), the study combines the effects of exogenous policy shocks and endogenous responses to the shocks concurrently. The study also uses the approach of Mountford and Uhlig (2009) to determine the shocks of fiscal policy as government revenue and government spending shocks, respectively. In this study, there is a standard procedure to obtain the VAR system while identifying the shocks with the help of sign restrictions.

According to the Uhlig's (2005) sign restrictions for monetary policy shocks, there is a positive restriction on the interest rate. However, there exists a negative restriction on the interest rate and the price level. In addition, the business cycle shock acts together with output, government revenue, consumption and investment in the same direction positively. 
The study includes the orthogonality assumption. This assumption enables the government revenue to avoid the process of being linked for unexpected tax cuts. An increase in taxes lead to the correlated and similar movements of government revenue and output in the model. Hence, the strength of fiscal policy is avoided by the orthogonality assumption in order to obtain beneficial results for the effects of fiscal policy shocks.

As noted before, the study adopts the sign restrictions, which are identified by Mountford and Uhlig (2009). The sign restrictions specify the limitations for the conditions of the sign on the impulse responses for each shock. There are ten variables in the VAR model of the study. According to the Mountford and Uglig (2009), there is a positive restriction on the impulse responses of the variables such as government revenue and government spending. This response is positive for four quarters after the shock. In simpler terms, the fiscal policy shocks, which are government revenue and government spending shocks re determined by the positive restrictions on the impulse responses of fiscal variables. These shocks present a positive limit on four quarters after the shock.

\section{Data}

The study focuses on the data for Turkey. The sample data is gathered from the Central Bank of the Republic of Turkey. The analyses are made for the period between 1988:Q1 and 2014:Q2. The aim is to demonstrate the relationship between asset prices and fiscal policy shocks in Turkey through B-VAR models. The sample data consists of important variables that are government revenue, government spending, GDP, consumption, investment, interest rate, wage rate, CPI and asset prices. All variables -except interest rate in the sample are determined in real per capita terms. The real per capita terms are calculated by dividing the nominal values of the variables by the CPI.

According to Schwartz Bayesian Information Criterion, the model is acquired on 4 lags. The model does not include a time trend and a constant value. Since this model uses sign restrictions, the government spending and government revenue shocks are determined for each draw from the posterior by plotting the 16th, 50th and 84th quantiles in the study.

\section{Empirical Results}

This section is devoted to illustrate four figures. In these figures, the aim is to show the impulse responses of the sample data for the period between 1988:Q1 and 2014:Q4. Each figure demonstrates the changing responses of ten variables. As noted before, the fiscal policy shocks, business cycle shocks and monetary policy shocks are determined are determined according to the sign restrictions.

The impulse responses for the fiscal policy shocks, monetary policy shocks and business cycle shocks are presented for then variables in four different figures. In each figure, the graphs show the 16th, 50th and 84th quantiles of the impulse responses. In order to illustrate the impulse responses properly, the calculation is made at each horizon by specifying the quarters between zero and twenty-four after the shock replaces.

\section{The Analysis of Government Revenue Shock}

Due to the orthogonality assumption, the government revenue shock is constructed as a resting position orthogonally to the business cycle shocks and monetary policy shocks. Therefore, there is an increase in government revenue for a period after the shock exists. Figure 1 presents the outcomes of the analyses of ten variables in the VAR. The graphs exhibit the impulse responses for the discussion. 

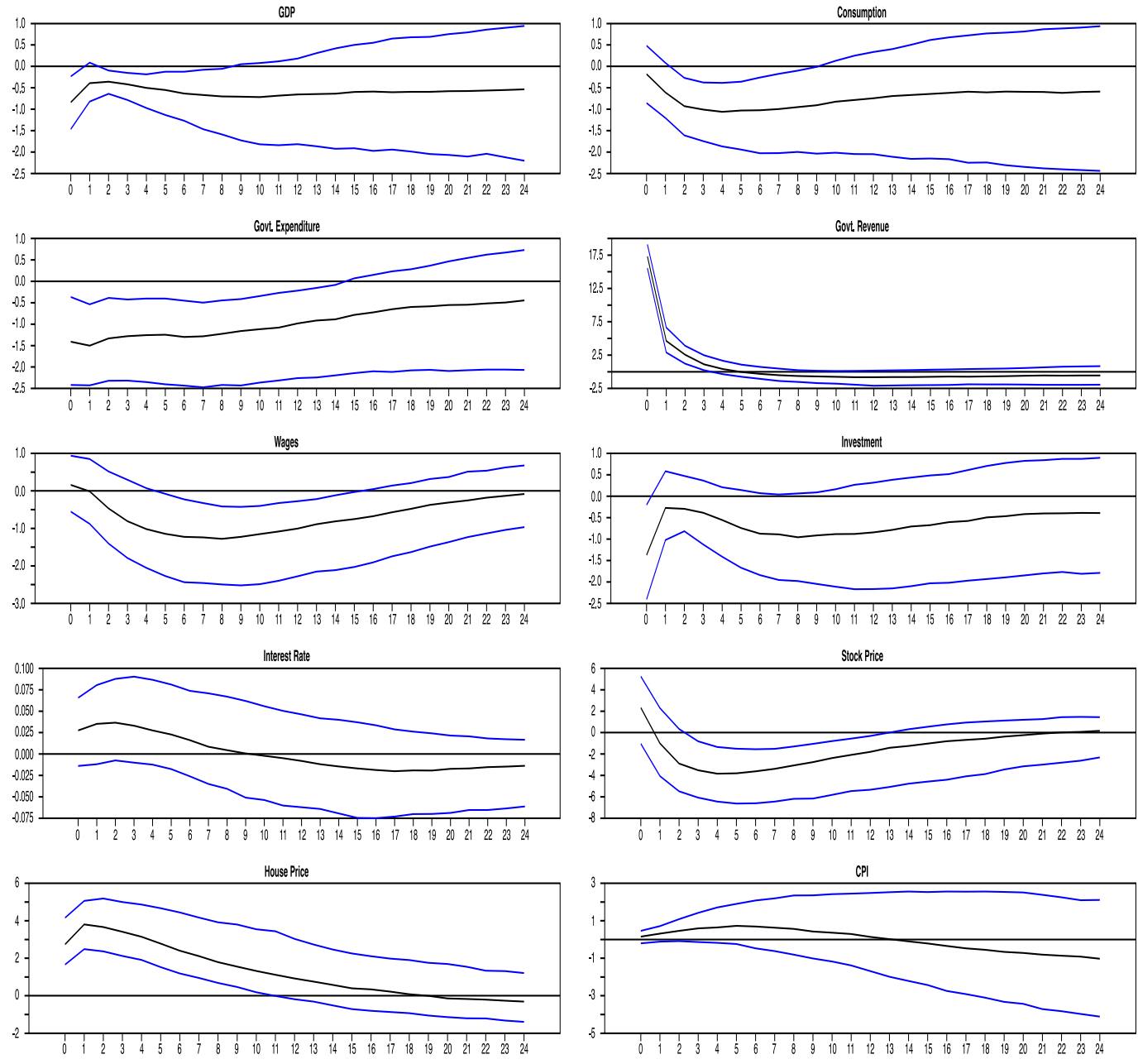

Figure 1. The Impulse Responses of Ten Variables: Government Revenue Shock

For example, when there is a positive government revenue shock, there exists a contractionary impact of this shock on the economy. There are significant and negative responses of GDP, consumption, wages and nonresidential investment to the government revenue shock. This shock adversely influences GDP and the consumption of households. In addition, the initial responses of the real house prices and stock prices are significant and positive. After the shock exists, the real house prices and stock prices start to fall significantly for the sample.

The government revenue shock leads to a decline in the deficit of fiscal policy. This influence automatically reduces the treasury bill price and increases the interest rate. Thus, Figure 1 illustrates a positive response of interest rate and CPI to the government revenue shock. As noted before, there is a decline in GDP. This decline results in a decrease in stock prices while nonresidential investment is responding negatively to the government revenue shock. In other words, the performance of the stock market is influenced adversely due to the negative responses of the stock prices.

\section{The Analysis of Government Spending Shock}

In order to express the influence of government spending shock, the outcomes of the impulse responses of ten variables are illustrated in Figure 2. As stated before, government spending shock is defined as a fiscal spending shock. Government spending shock is also constructed to remain orthogonal to the business cycle and monetary policy shocks. Therefore, the government spending shows a persistent increase for a year after the shock exists. 

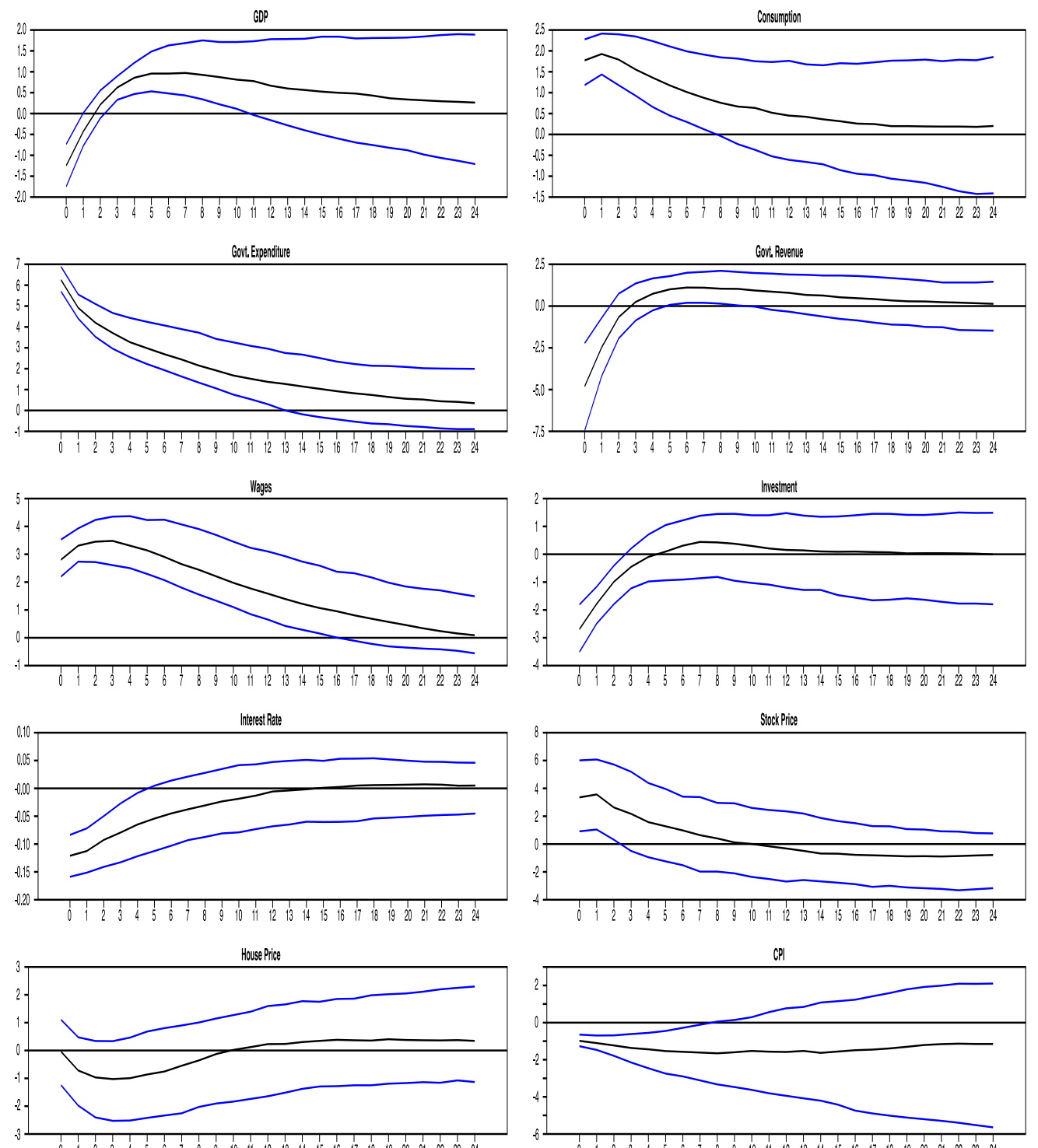

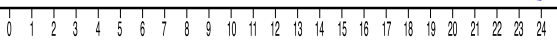

Figure 2. The Impulse Responses of Ten Variables: Government Spending Shock

When there is a positive shock to the government spending, there is an expansionary influence on the economy. Due to the existence of government spending shock, consumption and wages respond significantly and positively. The initial response of GDP to the government spending shock is significant and negative, but then it starts to respond positively for the entire sample.

\section{The Analyses of Business Cycle Shock and Monetary Policy Shock}

The impulse responses of the ten variables are analyzed in this section of the study. It is seen that in Figure 3, the stock prices respond significantly and positively for the entire sample if there is a positive business cycle shock. There is also a positive impact of a business cycle shock on the real house prices. The CPI also exhibits a significant and positive response because the demand increases in a small-open economy. 


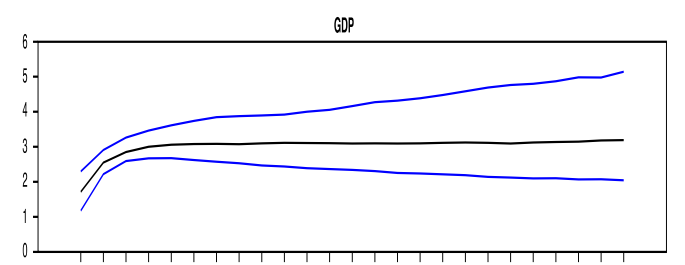

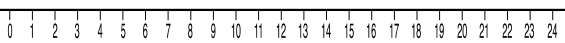

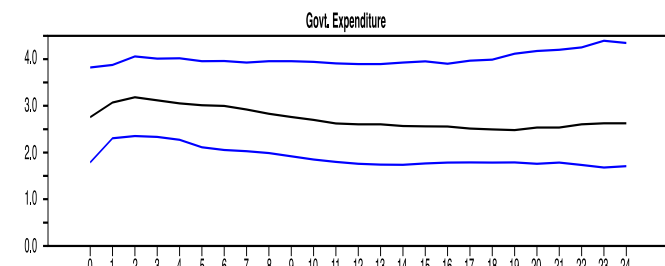

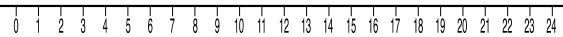

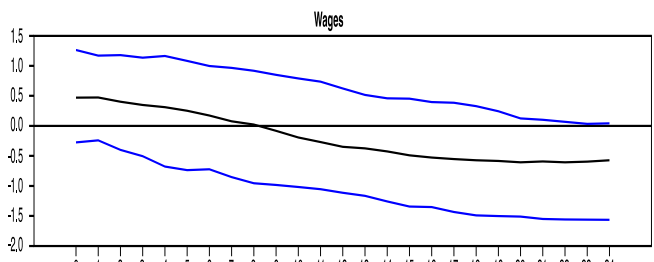

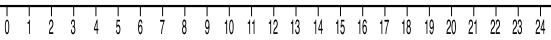

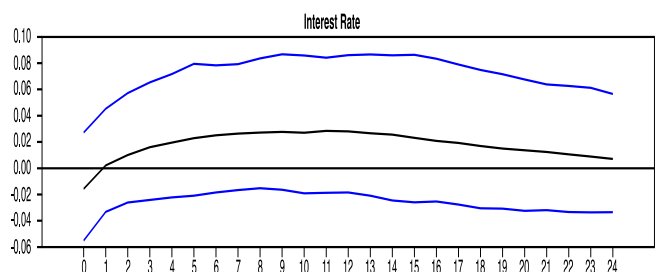

House Price

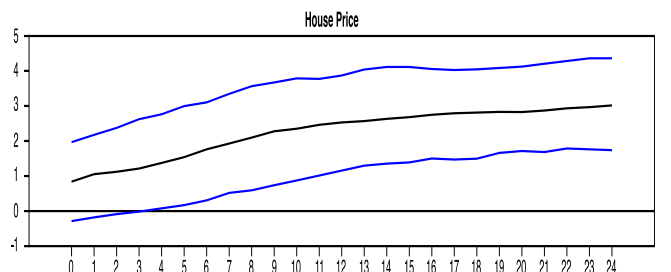

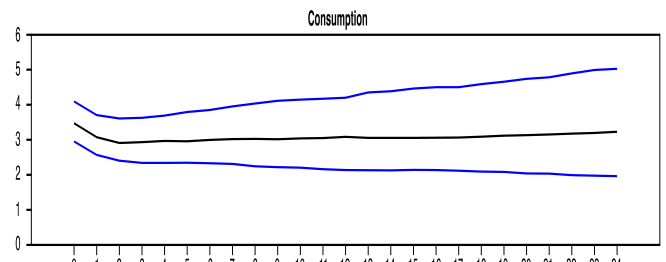

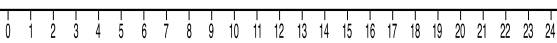

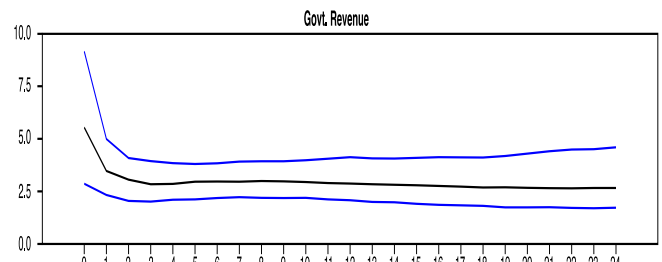

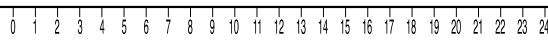

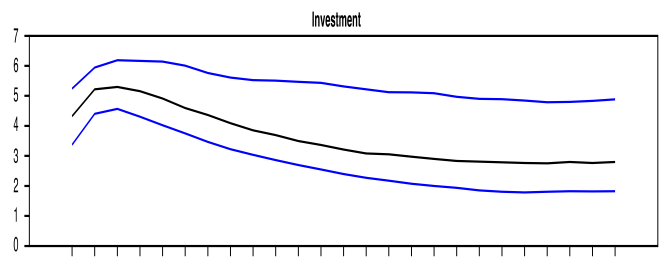

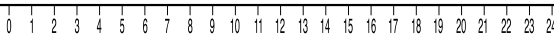
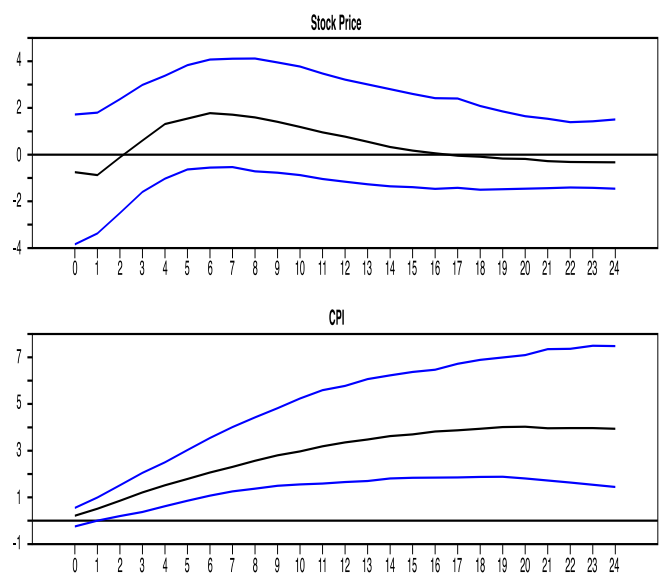

Figure 3. The Impulse Responses of Ten Variables: Business Cycle Shock

In addition, the impulse responses of ten variables in the VAR are presented in Figure 4. The real stock prices respond negatively and significantly to the monetary policy shock. In Figure 4, the real house prices exhibit a significant and positive response to the monetary policy shock.

However, the nonresidential investment and CPI respond significantly and negatively. The responses to the monetary policy shock of GDP, consumption, wages and interest rate, are significant and positive. It is also seen that the effect of the monetary policy shock on government expenditure and government revenue is examined, their responses are significant and positive. 

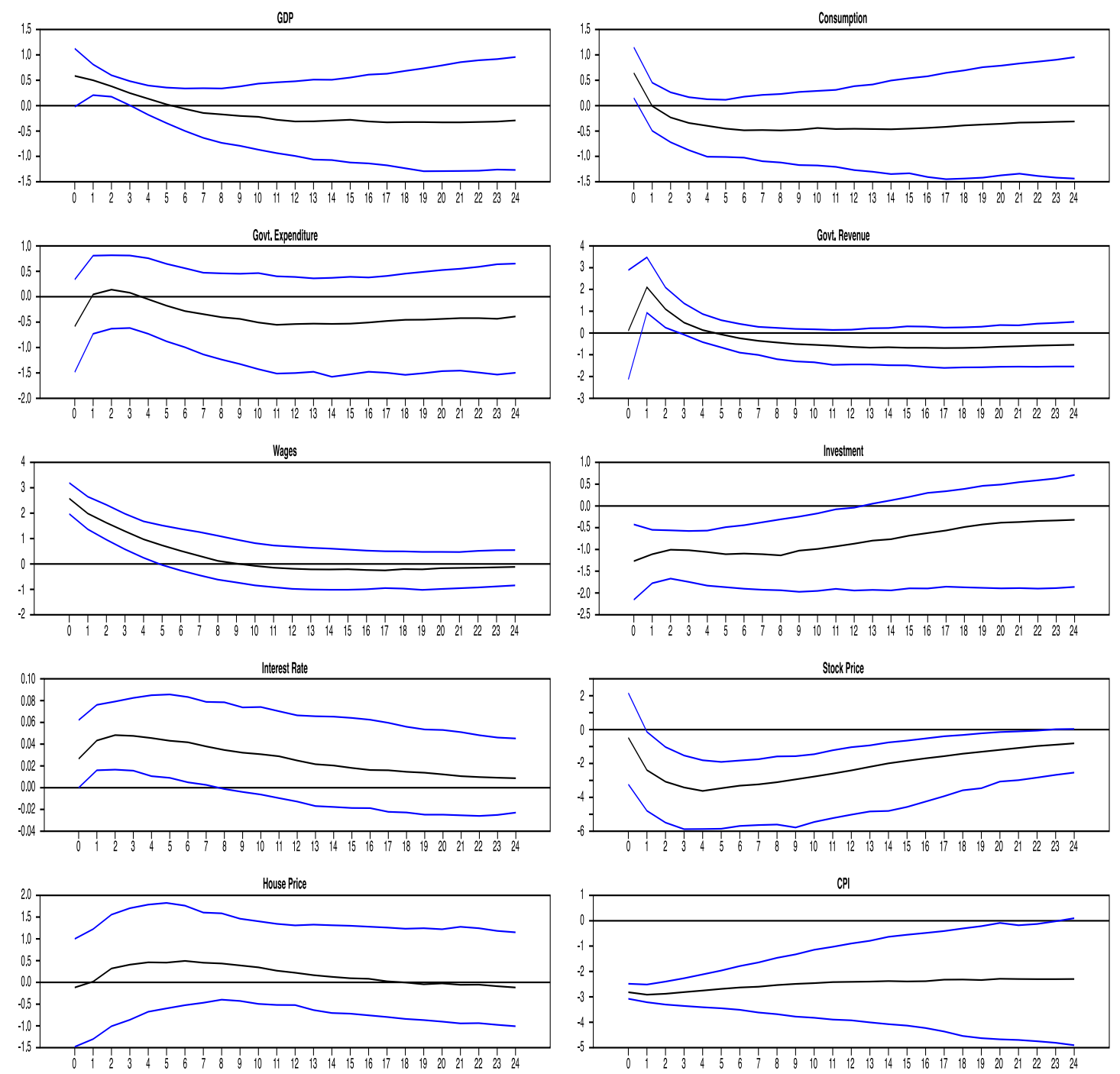

Figure 4. The Impulse Responses of Ten Variables: Monetary Policy Shock

\section{Conclusion}

In this study, the B-VAR models are used to examine the impact of fiscal policy shocks on stock prices and house prices. The VAR system includes ten variables, which are government revenue, government consumption, GDP, wages and nonresidential investment, stock prices, house prices and interest rate. The approach of Uhlig (2005) and Mountford and Uhlig (2009) is used to obtain outcomes. The sign restrictions are determined in order to get the beneficial results in the econometric method of the study.

According to the research findings, if there is a positive government revenue shock, this fact adversely influences the stock prices and house prices, respectively. On the other hand, where there is a positive shock to government spending, the stock prices have a significant and positive response whereas the house prices don't respond significantly. The results confirm that the spending shocks affect stock prices more than the house prices. In addition, the government revenue shock is more influential than the government spending shock when the responses of real house prices are taken into consideration. In this respect, it is very hard to provide a balance for policy makers because the responses of the stock prices and house prices vary when the fiscal policy shocks are examined. The study also shows that a positive monetary shock results in a contraction in Turkey. When there is a positive business cycle shock, the real stock prices and house prices respond significantly and positively. In conclusion, this study provides beneficial results for business cycle shocks, monetary policy shocks and fiscal policy shocks in Turkey. 


\section{References}

- Afonso, Antonio, and Ricardo M. Sousa. 2011. "What Are the Effects of Fiscal Policy on Asset Markets?" Economic Modelling 28:1871-90.

- Afonso, Antonio, and Ricardo M. Sousa. 2012. “The Macroeconomic Effects of Fiscal Policy.” Applied Economics 44:4439-54.

- Agnello, Luca, Vitor Castro, and Ricardo M. Sousa. 2012. "How Does Fiscal Policy React to Wealth Composition and Asset Prices?" Journal of Macroeconomics 34:874-90.

- $\quad$ Anand, Ritu, and Sweder Van Wijnbergen. 1989. "Inflation and the financing of government expenditure: an introductory analysis with an application to Turkey." The World Bank Economic Review 3(1): 17-38.

- Aye, Balcilar et al. 2013. "Fiscal Policy Shocks and the Dynamics of Asset Prices: The South African Experience.” Public Finance review 00(0):1-21.

- Bjørnland, Hilde C., and Kai Leitemo. 2009. "Identifying the Interdependence between US Monetary Policy and the Stock Market." Journal of Monetary Economics 56:275-82.

- Caporale, Guglielmo Maria, and Ricardo M. Sousa. 2015. "Consumption, wealth, stock and housing returns: evidence from emerging markets." Research in International Business and Finance.

- Castro, Vitor. 2011. “Can Central Banks' Monetary Policy be Described by a Linear (Augmented) Taylor Rule or by a Nonlinear Rule?” Journal of Financial Stabi- lity 7:228-46.

- Coskun, Yener. 2011. "Global Financial Crisis and Turkish Housing Market: Is There A Success Story?" Housing Finance International 25(3):6-14.

- Ertuğrul, Ahmet, and Faruk Selçuk. 2001. "A brief account of the Turkish economy, 1980-2000." Russian and East European Finance and Trade 1:6-30.

- Mountford, Andrew, and Harald Uhlig. 2009. "What are the Effects of Fiscal Policy Shocks?” Journal of Applied Econometrics 24:960-92.

- Schuknecht, Ludger, Jurgen von Hagen, and Guido Wolswijk. 2009. "Government Risk Premiums in the Bond Market: EMU and Canada.” European Journal of Political Economy 25:371-84.

- Sims, Christopher A. 1972. "Money, Income and Causality.” American Economic Review 62:540-52.

- Sims, Christopher A. 1980. "Macroeconomics and Reality." Econometrica 48:1-48.

- Sousa, Ricardo M. 2010. "Housing Wealth, Financial Wealth, Money Demand andPolicy Rule: Evidence from the Euro Area." The North American Journal ofEconomics and Finance 21:88-105.

- Stock, James H., and Mark W. Watson. 2003. "Understanding Changes in Interna-tional Business Cycle Dynamics.” National Bureau of Economic ResearchWorking Papers, Cambridge, MA.

- Uhlig, Harald. 2005. "What are the Effects of Monetary Policy on Output? Resultsfrom an Agnostic Identification Procedure.” Journal of Monetary Economics 52:381-419.

- Voyvoda, Ebru and Erinc Yeldan 2005. Turkish Macroeconomics under the IMF Program: Stangulation of the Twin-Targets, Lopsided Growth and Persistent Fragilities. Bağımsız Sosyal Bilimciler Working Paper.

- Yeldan, Erinc A. 1997. "Financial Liberalization and Fiscal Repression in Turkey: Policy Analysis in a CGE Model with Financial Markets. Journal of Policy Modeling 19(1): 79-117. 